\title{
引張試験によるスケール密着性評価
}

\author{
山田遥平中久保昌平＼cjkstart武田実佳子
}

株式会社神戸製鋼所材料研究所

J. Japan Inst. Met. Mater. Vol. 81, No. 4 (2017), pp. 206-210

(C) 2017 The Japan Institute of Metals and Materials

\section{Evaluation of Adhesion of Oxide Scale by Tensile Test}

Yohei Yamada, Shohei Nakakubo and Mikako Takeda

Materials Reserch Laboratory, KOBE STEEL, LTD, Kobe 651-2271

In the hot rolling process, the external appearance of steel can deteriorate due to spalling of oxide scales. We used a tensile test in order to evaluate and quantify the adhesion of the scales in the hot rolling process. When loaded with tensile stress, the behavior of the scales goes through the following three stages:

(1) The scales have only residual stress

(2) The scales and the steel are both elastically deformed

(3) The scales are elastically deformed but the steel is plastically deformed.

For these three stages, the strain energy accumulated in the scales before spalling was calculated and then the adhesion energy was derived. For about $4 \mu \mathrm{m}$ thick scales on $99.9 \% \mathrm{Fe}$ and $\mathrm{Fe}-1.0 \% \mathrm{C}$ the adhesion energies were $1.70 \mathrm{~J} / \mathrm{m}^{2}$ and $36.2 \mathrm{~J} / \mathrm{m}^{2}$, respectively. The adhesion energies determined by a scratch test were $2.90 \mathrm{~J} / \mathrm{m}^{2}$, and $31.6 \mathrm{~J} / \mathrm{m}^{2}$ each. Thus, the results of the two tests are approximately in agreement. [doi:10.2320/jinstmet.JBW201603]

(Received November 17, 2016; Accepted December 26, 2016; Published February 3, 2017)

Keywords: iron oxide scale, adhesion energy, tensile test, scratch test

\section{1. 緒言}

鋼材の熱間製造プロセスにおいて，表面には酸化皮膜(ス ケール)が生成する，近年の品質要求の高まりから，優れた表 面外観を有する鋼材が求められているが, 赤スケールやス ケールの剥離が発生すると鋼材の表面外観は著しく劣化する. 赤スケールは鋼材表面の粉末状 $\mathrm{Fe}_{2} \mathrm{O}_{3}$ が原因であり, 圧延前 のデスケーリングでスケールが取りきれず残存すると, 圧延 により砕かれて赤スケールが発生する ${ }^{1-4)}$. 一方, スケールの 剥離は圧延, 冷却中, あるいは巻取り時など熱間圧延の高温 プロセスで発生し，それぞれの工程でのスケールの密着性の 改善が求められる. スケール起因の表面外観不良を抑制する ためには，スケールの密着性を把握することが重要である.

スケール密着性には鋼成分, 製造条件などが影響を及ぼす ことが知られている. 例えば, 鋼材に $\mathrm{Si}$ や Cr が添加されて いる場合はスケール/鋼界面に濃化層が形成するため, 密着性 が向上する5)ことや，仕上げ圧延温度とコイル巻き取り温度 の低温化はスケールの厚さを低減させ, 密着性を向上させる ${ }^{6)}$ こと, また, 高温環境下でのスケールの密着性については鋼 成分の違いによるブリスターの発生状況により考察されてお り， C, Mn， P 量の増加によりブリスターの発生が促進され ること7)が報告されている.

一方, スケールの密着性の評価手法については, 高温環境 で定量評価した報告は少ない。例えば，スケールを生成させ

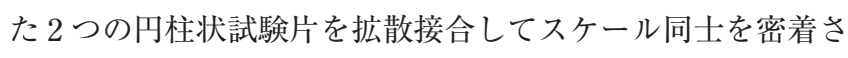

せた後, 引張試験によりスケールを剥離させる手法が報告さ れている ${ }^{8)}$ が, スケールは生成温度によって組成が変化し， ス

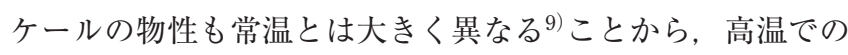
スケール密着性の定量評価は困難である。 そのため, 確固と した密着性評価手法は確立されていない.

筆者らはスケールの密着性を定量評価する手法として引張 試験に着目した。この理由としては, 引張試験は高温でも測 定が容易であり, 他手法よりもスケールの剥離挙動の観察が 容易であるためである，本研究では，スケール密着性の定量 評価手法を確立するため, スケールを生成させた試験片の常 温での引張試験を行った。ささらにスクラッチ試験による結果 と比較することで, スケール密着性の定量值の妥当性を検証 した，本報ではスケール密着性の評価手法と定量的解析，お よびスケール性状や応力の影響を検討した結果を述べる.

\section{2. 評 価 方 法}

\section{1 引張試験によるスケール密着性の評価}

密着力は基材から薄膜を引き剥がすのに必要なエネルギー とされ, 薄膜と基材が界面エネルギー $\gamma_{\mathrm{fs}}$ でもって一体化した 状態から薄膜 (表面エネルギー $\gamma_{\mathrm{f}}$ ) と基材 (表面エネルギー $\gamma_{\mathrm{s}}$ ) の 2 つの自由表面に等温可逆的に分離するために必要な仕事 (エネルギー)が密着力であり, Dupre の式 : $\mathrm{G}=\gamma_{\mathrm{f}}+\gamma_{\mathrm{s}}-\gamma_{\mathrm{fs}}$ で 表され， Gを密着エネルギーと呼ぶ ${ }^{10)}$.

本研究では, 密着エネルギーによりスケール密着性の定量 評価を行った，密着エネルギーを直接的に測定することは困 
難であるが，引張試験ではひずみエネルギーから密着エネル ギーを求めることが可能である. スケールに外力が負荷され た場合, スケールに蓄積するひずみエネルギーがスケールの 密着エネルギーを上回った時に剥離が発生し, 剥離条件は式 (1) で表される11)

$$
G \leq u \times t
$$

$G:$ スケールの密着エネルギー $\left(\mathrm{J} / \mathrm{m}^{2}\right)$

$u$ : スケールに蓄積する単位体積あたりのひずみエネルギー $\left(\mathrm{J} / \mathrm{m}^{3}\right)$

$t:$ スケール厚さ $(\mathrm{m})$

つまり，剥離が起こった瞬間の $u$ と $t$ が分かれば密着エネル ギー $\mathrm{G}$ を導出することが可能である. 引張試験におけるひず みエネルギーはスケールにかかる応力をひずみで積分するこ とで求めることができ, 式 $(2)$ で表される.

$$
\mathrm{u}=\int \sigma d \varepsilon
$$

次にスケールにかかる応力を求める方法について述べる．引 張試験時のスケール状態は以下の三段階に分けられることが 提唱されている12)

Stage 1：スケールには残留応力のみかかっている状態

Stage 2：スケールと鋼がともに弾性変形をしている状態

Stage 3 : スケールは弾性変形をするが, 鋼は塑性変形をし ている状態

これらの三段階の引張応力負荷前, 鋼の降伏点, スケール剥 離点おけるスケールにかかる応力とひずみの関係は以下の式 で表される12).

$$
\begin{gathered}
\sigma_{1}=\sigma_{r e s}=E_{o x} \varepsilon_{r e s} /\left(1-v_{o x}\right) \\
\sigma_{2}=E_{o x}\left(1-v_{m} v_{o x}\right)\left(\varepsilon_{2}-\varepsilon_{r e s}\right) /\left(1-v_{o x}^{2}\right)+\sigma_{1} \\
\sigma_{3}=E_{o x}\left(1-v_{o x} / 2\right)\left(\varepsilon_{3}-\varepsilon_{2}\right) /\left(1-v_{o x}^{2}\right)+\sigma_{2}
\end{gathered}
$$

$\sigma$ : 応力 $(\mathrm{Pa}), E_{o x}$ : スケールのヤング率 $(\mathrm{Pa}), \varepsilon$ : ひずみ, $v_{o x}$ : スケールのポアソン比, $v_{m}$ : 鋼のポアソン比

これらの応力，ひずみを導出することで，ひずみエネルギー の算出が可能である. 本研究では鋼とスケールに同等のひず みが蓄積されると仮定し, それぞれの導出を行った， $\sigma_{1}$ はス ケール中の残留応力であり, 残留応力が分かれば式 $(3)$ より 残留応力によるスケールのひずみ $\varepsilon_{r e s}$ を求めることができる. なお, 残留応力はXRDにより測定可能である， $\sigma_{2}$ は鋼の降伏 点でのスケールの応力であり, $\varepsilon_{2}$ を鋼の降伏点のひずみから

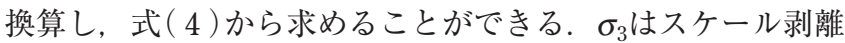
時にスケールにかかっている応力であり，このときの鋼のひ ずみから $\varepsilon_{3}$ を換算し，式 $(5)$ より導出可能である。式 $(3)-$ (5) から想定されるスケールの応力ひずみ曲線は Fig. 1 に示 す。図中の斜線で示した部分の面積を算出することで単位体 積あたりのひずみエネルギーとし，これにスケール厚さを掛 けることでスケールの密着エネルギーを導出することができ る.

\section{2 スクラッチ試験によるスケール密着性の評価}

引張試験により求めたスケールの密着性の定量値の妥当性 を検証するため, スクラッチ試験により密着性を評価した. スクラッチ試験によって求めることのできる值は剥離時の垂 直荷重や摩擦力である。しかし, これらの值は膜の残留応力

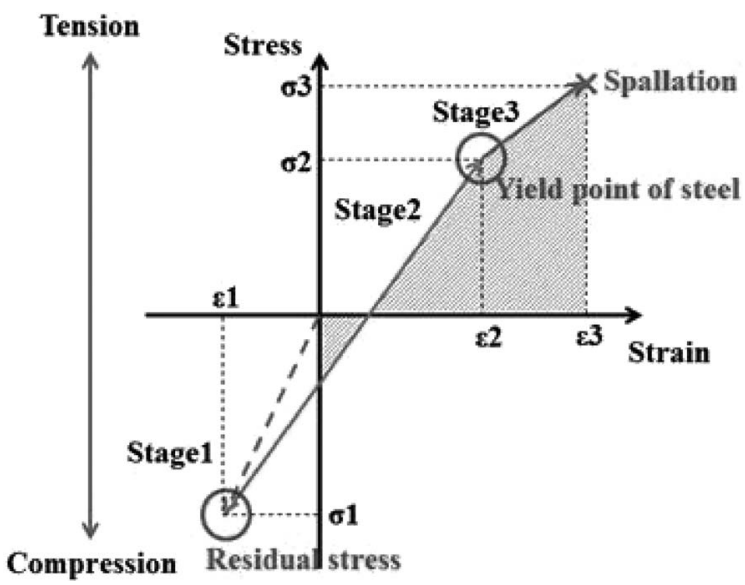

Fig. 1 Stress-strain curve of the oxide for the scale-steel system.

や膜の硬さ，基材の硬さなどに影響を受けるため，界面の密 着力を測定しているとは言えない. そこで, 本研究ではスク ラッチ試験における密着エネルギーを式 ( 6 )により求めた ${ }^{13)}$.

$$
\mathrm{G}=\left(v\left(\mu_{c} L_{c} / A+\sigma_{r e s}\right)\right)^{2}(t / 2 E)
$$

$\mathrm{G}$ : 密着エネルギー $\left(\mathrm{J} / \mathrm{m}^{2}\right)$

$L_{c}:$ 剥離荷重 $(\mathrm{N})$

$\mu_{c}:$ 剥離荷重時の摩擦係数

$v$ : スケールのポアソン比

$A$ : スクラッチ痕の断面積 $\left(\mathrm{m}^{2}\right)$

$\sigma_{r e s}:$ スケールの残留応力 $(\mathrm{Pa})$

$t:$ スケール厚さ $(\mathrm{m})$

$E:$ スケールのヤング率 $(\mathrm{Pa})$

このときスクラッチ痕の断面積は以下の式で表される ${ }^{13)}$.

$$
A=R^{2} \sin ^{-1}(d / 2 R)-(d / 2)\left\{R^{2}-(d / 2)^{2}\right\}^{1 / 2}
$$

$A$ : スクラッチ痕の断面積 $\left(\mathrm{m}^{2}\right)$

$R:$ 圧子先端の曲率半径 $(\mathrm{m})$

$d:$ スクラッチ痕の幅 $(\mathrm{m})$

最初に基材が見えた箇所を剥離点とし，このときの剥離荷重 と摩擦係数, スクラッチ痕の幅を読み取り, 式 $(6)$ および ( 7 ) から密着エネルギーを求めた

\section{3. 実 験 方 法}

99.9\%純鉄および $\mathrm{Fe}-1.0 \% \mathrm{C}$ を供試材とした。これらの材 料から $90 \mathrm{~mm} \times 10 \mathrm{~mm} \times 2 \mathrm{~mm}$ の短冊状の引張試験片を切出 した，表面はエメリー紙＃600で研磨し，酸化前にアセトンで 超音波洗浄をした。 $\mathrm{Fe}_{2} \mathrm{O}_{3}$ を抑制するため, $\mathrm{N}_{2}-1 \% \mathrm{O}_{2}$ で䨌囲 気制御し， $850^{\circ} \mathrm{C}$ で 20 秒間酸化した。その後 $\mathrm{N}_{2}$ 中で泠却し， $\mathrm{FeO}$ から $\mathrm{Fe}_{3} \mathrm{O}_{4}$ に変態させるため $550^{\circ} \mathrm{C}$ から $400^{\circ} \mathrm{C}$ までを 3600 秒間で徐冷し，表面にスケールを生成させた。試験片を切断 した後樹脂に埋め込み，SEMを用いて断面からスケールの厚 さを測定した，スケール組成および残留応力はXRD を用いて 測定した，XRDの測定条件はターゲット：Co, 検出器：一次 元検出器, ターゲット出力 $40 \mathrm{kV}-135 \mathrm{~mA}$, 測定は $\theta / 2 \theta$ 走 査でスリット：発散 $2 / 3^{\circ}$, 散乱 $20^{\circ}$, 受光 $20 \mathrm{~mm}$, 走査速度 $20^{\circ} / \mathrm{min}$, サンプリング幅 : $0.01^{\circ}$, 測定角度 $(2 \theta): 15 \sim 110^{\circ}$ と 
した。 また， X 線残留応力測定は「日本材料学会 $\mathrm{X}$ 線材料強 度部門委員会 $X$ 線応力測定法標準」に基づき $\sin ^{2} \psi$ 法で行っ た. 残留応力が存在する場合, X 線の入射角 $(\psi)$ を変えると 回折線のピーク位置が変化する。変化した回折線のピーク位 置を縦軸, $\mathrm{X}$ 線入射角の $\sin ^{2} \psi$ を横軸にとり最小二乗法によ り直線回帰してその傾きを求めた. 得られた傾きにヤング率, ポアソン比から求めた応力定数を乗じて応力值を換算した. なお, 応力定数の值は, ヤング率とポアソン比から算出した 応力定数を使用した.

$$
\sigma=-\frac{\mathrm{E}}{2(1+v)} \cdot \cot \theta_{0} \cdot \frac{\pi}{180} \cdot \mathrm{M}=\mathrm{K} \cdot \mathrm{M}
$$

$\sigma$ : 応力值 $(\mathrm{MPa})$

$\mathrm{E}:$ ヤング率 $(\mathrm{MPa})$

$v:$ ポアソン比

$2 \theta_{0}:$ 無歪みの回折角 (deg.)

$\mathrm{K}$ : 応力定数 $(\mathrm{MPa} / \mathrm{deg}$. $)$

$\mathrm{M}$ ：回帰直線 $2 \theta-\sin ^{2} \psi$ の傾き

\section{1 引張試験方法}

引張試験機はインストロン製5982型万能試験システムを用 い, 上記の試験片において室温で引張試験を行った. クロス ヘッド速度により引張速度を $0.21 \mathrm{~mm} / \mathrm{s}$ に制御し，ひずみ ゲージによりひずみを測定した。 スケールの剥離挙動の観察 はビデオカメラを用いて行い，最初に剥離が観察された瞬間 のひずみを読み取った. Fig. 2 に引張試験前後の試料外観写 真を示す. 図中に示すように, 鋼素地の露出を剥離とした.

\section{2 スクラッチ試験方法}

スクラッチ試験機は CSM Instruments 社製 CH-2007を用い た. スクラッチ圧子の先端形状は対頂角 120 度, 先端曲率半径 $0.2 \mathrm{~mm}$ の円錐状である. スクラッチ走査条件は荷重付加速度
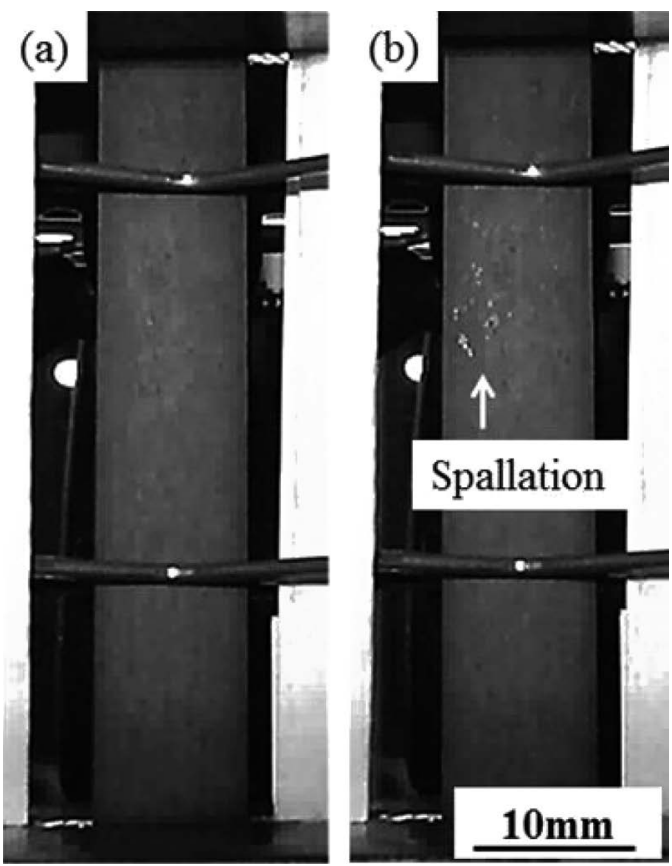

Fig. 2 Appearances of surface (a) before tensile test (b) after tensile test.
$50 \mathrm{~N} / \mathrm{mm}$, 走査速度 $5 \mathrm{~mm} / \mathrm{min}$ とした. スクラッチ痕および 剥離箇所は光学顕微鏡で観察し, スクラッチ開始点から剥離 開始点までの距離から剥離時の垂直荷重を求めた。さらに剥 離時の摩擦力から摩擦係数を算出した.

4. 結果

\section{1 引張試験による密着エネルギーの評価}

スケールの残留応力 $\sigma_{\mathrm{res}}$ はXRDにより測定し, $99.9 \%$ 純鉄 で -244.1 MPa, Fe-1.0\%Cで-170.5 MPaであった. 式(3 ) より Stage 1 でのひずみ $\varepsilon_{\text {res }}$ はそれぞれ $-0.085 \%,-0.060 \%$ と 算出した. Stage 2 の鋼の降伏点におけるスケールのひずみ $\varepsilon_{2}$ は鋼の降伏点のひずみから $\varepsilon_{\mathrm{res}}$ を除くことで求めることがで きる。しかし， 99.9\%純鉄と $\mathrm{Fe}-1.0 \% \mathrm{C}$ のいずれも降伏現象 が確認されなかったため, 鋼の降伏点のひずみを $0.2 \%$ と仮定 し， $\varepsilon_{2}$ をそれぞれ $0.115 \% ， 0.140 \%$ とした．鋼の降伏点でのス ケールにかかる応力 $\sigma_{2}$ は式 (4) から $155.9 \mathrm{MPa}, 229.5 \mathrm{MPa}$ と導出できた，スケール剥離時の鋼のひずみから換算したス ケールのひずみ $\varepsilon_{3}$ は $0.235 \%, 1.040 \%$ であり, 式 $(5$ ) より剥離 時のスケールにかかる応力 $\sigma_{3}$ は $380.1 \mathrm{MPa}, 1910.8 \mathrm{MPa}$ で あった。 なお，これらの計算に必要なスケールのヤング率と ポアソン比はそれぞれ $\mathrm{E}_{\mathrm{ox}}=200 \mathrm{GPa}, v_{\mathrm{ox}}=v_{\mathrm{m}}=0.3$ とした. これらの值により得られる剥離までのスケールの応力ひずみ 曲線を Fig. 3 に示す. このグラフから式 $(2$ ) よりひずみエネ ルギーを算出し，それぞれのスケール厚さ $4.2 \mu \mathrm{m}, 3.7 \mu \mathrm{m}$ を 掛けることにより密着エネルギーを導出した。 これらの結果 を Table 1 にまとめた。 密着エネルギーは純鉄で $1.70 \mathrm{~J} / \mathrm{m}^{2}$, $\mathrm{Fe}-1.0 \% \mathrm{C}$ で $36.2 \mathrm{~J} / \mathrm{m}^{2}$ となった. いずれの鋼も降伏点のひず みを $0.2 \%$ と仮定したため, Stage 2 まで(鋼の降伏点まで)の 挙動は応力ひずみともほとんど差異は無いが, Stage 3(降伏

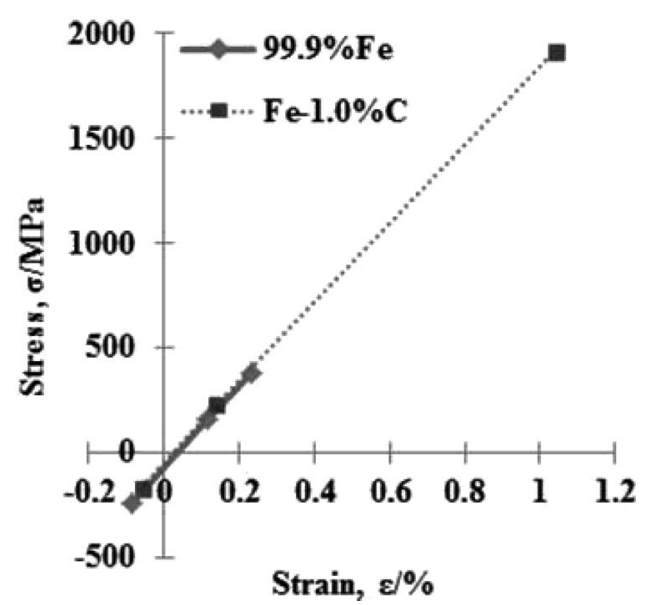

Fig. 3 Stress-strain curves of oxide scale for steel-scale system.

Table 1 Stress and strain at each stages, and adhesion energy.

\begin{tabular}{cccccccc}
\hline & \multicolumn{2}{c}{ stage1 } & \multicolumn{2}{c}{ stage2 } & \multicolumn{2}{c}{ stage3 } & $\begin{array}{c}\text { Adhesion } \\
\text { energy, }\end{array}$ \\
\cline { 2 - 7 } & $\sigma_{\text {res }} / \mathrm{MPa}$ & $\varepsilon_{\text {res }} / \%$ & $\sigma_{2} / \mathrm{MPa}$ & $\varepsilon_{2} / \%$ & $\sigma_{3} / \mathrm{MPa}$ & $\varepsilon_{3} / \%$ & \\
$\mathrm{G} / \mathrm{J} \cdot \mathrm{m}^{-2}$
\end{tabular}


点から剥離点まで)において $\mathrm{Fe}-1.0 \% \mathrm{C}$ の方が剥離までのひず み量が多かったため, 結果として密着エネルギーに差が生じ た。

\section{2 スクラッチ試験による密着エネルギーの評価}

スクラッチ試験を行った結果, スクラッチ痕内で基材の露 出が確認された。 スケールの剥離の起点部の写真を Fig. 4 に 示す。この部分でのスクラッチ痕幅を測定し, 式( 7 )よりス クラッチ痕断面積を求めた。さらに測定した剥離荷重と摩擦 係数から式 ( 6 ) より密着エネルギーを導出した。計算で用い たヤング率とポアソン比は同様にそれぞれ $\mathrm{E}=200 \mathrm{GPa}, v=$ 0.3 とした. Table 2 にスクラッチ試験の測定結果を示す。純 鉄に比べ $\mathrm{Fe}-1.0 \% \mathrm{C}$ では剥離荷重が高く, 摩擦係数が小さ かった。この結果, 密着エネルギーは純鉄で $2.90 \mathrm{~J} / \mathrm{m}^{2}$, $\mathrm{Fe}-1.0 \% \mathrm{C}$ で $31.6 \mathrm{~J} / \mathrm{m}^{2}$ となった。 これらは引張試験結果と概 ね一致している.

5. 考察

スケール性状と密着性の関係について考察をする。 $99.9 \%$ 純鉄および $\mathrm{Fe}-1.0 \% \mathrm{C}$ における酸化後のスケールの断面観察 写真を Fig. 5 に示す. Fe-1.0\%Cではスケールがわずかに薄
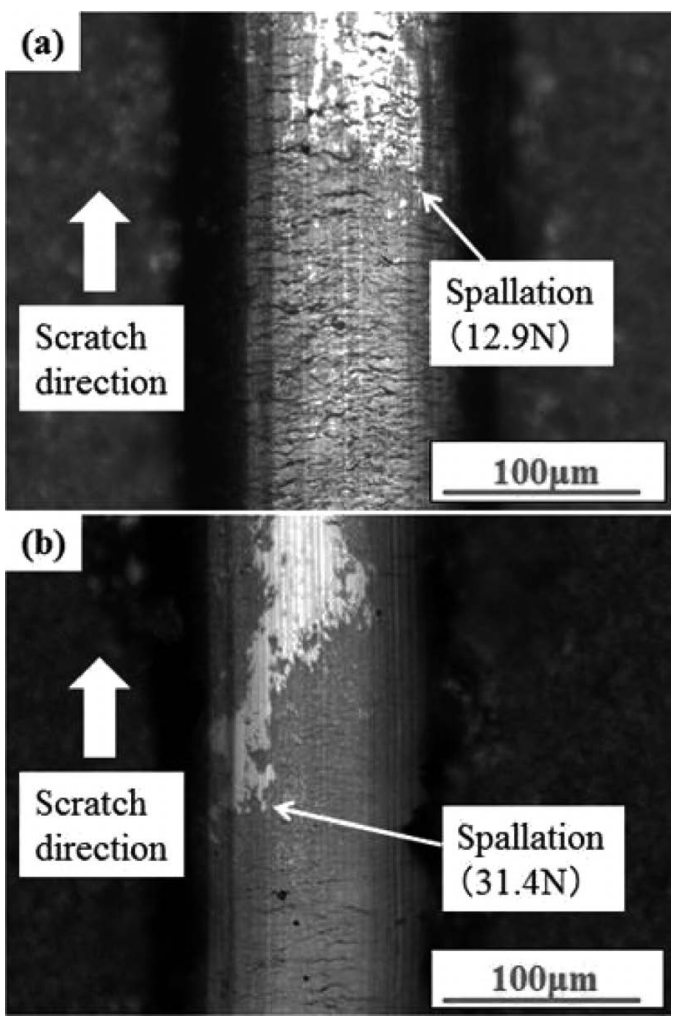

Fig. 4 Optical micrograph of scale after scratch test (a) 99.9\% $\mathrm{Fe}$ (b) $\mathrm{Fe}-1.0 \% \mathrm{C}$.
くなっており，ボイドが多くなっていることが確認された. また，XRD による分析ではいずれも $100 \% \mathrm{Fe}_{3} \mathrm{O}_{4}$ のスケールが 生成しているが, $\mathrm{Fe}-1.0 \% \mathrm{C}$ のイールは $99.9 \%$ 純鉄に比べ残 留応力が低減していることが確認された。これらを Table 3 にまとめた．スケールの残留応力はマイナス方向が圧縮応力 を示しており，酸化温度からの冷却に伴い，スケールと鋼の 熱膨張率の差から蓄積した熱応力であると考えられる。さら にスケール/鋼界面に着目すると， $\mathrm{Fe}-1.0 \% \mathrm{C}$ の方が，わずか に界面が粗くなる傾向が確認された。

スケール中のボイド量について，鋼にCが添加されている 場合は，加熱するとスケール生成とともに脱炭反応が進行す

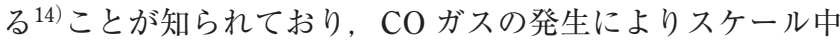
のボイド量が多くなると考えられる， $\mathrm{Fe}-1.0 \% \mathrm{C}$ では界面が 粗くなる傾向が見られたが，このボイドが Fe イオンの外方 拡散の障害となり，スケールの生成が不均一になったためと 推察される。界面粗さとスケール密着性の関係については不 明点が多いが，界面凹凸が大きいほど密着性が高いことが示 唆されており ${ }^{8)}, \mathrm{Fe}-1.0 \% \mathrm{C}$ では式 $(1$ )で示す密着エネルギー
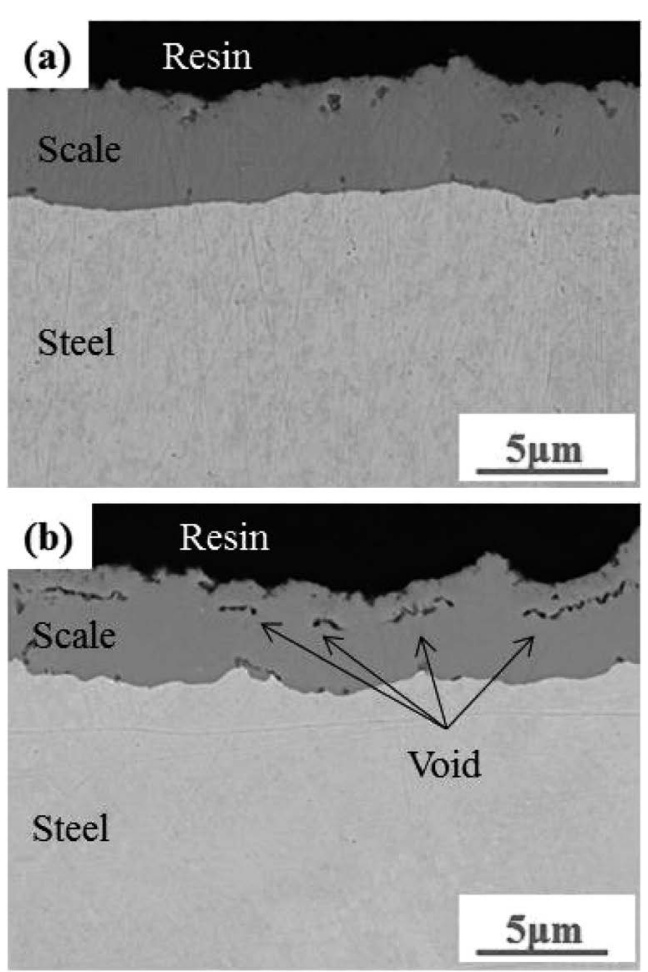

Fig. 5 Cross sections of scale of (a) $99.9 \% \mathrm{Fe}$ (b) $\mathrm{Fe}-1.0 \% \mathrm{C}$.

Table 3 Characterization of scale.

\begin{tabular}{cccc}
\hline & Composition & Scale thickness, $\mathrm{t} / \mu \mathrm{m}$ & Residual Stress, $\sigma_{\text {res }} / \mathrm{MPa}$ \\
\hline $99.9 \% \mathrm{Fe}$ & $\mathrm{Fe}_{3} \mathrm{O}_{4}$ & 4.2 & -244.1 \\
$\mathrm{Fe}-1.0 \% \mathrm{C}$ & $\mathrm{Fe}_{3} \mathrm{O}_{4}$ & 3.7 & -170.5 \\
\hline
\end{tabular}

Table 2 Adhesion energy for the scratch test.

\begin{tabular}{ccccc}
\hline & Critical load, $\mathrm{L}_{\mathrm{c}} / \mathrm{N}$ & Coefficient of friction, $\mu$ & $\begin{array}{c}\text { Cross-sectional area of } \\
\text { scratch mark, } \mathrm{A} / \mathrm{m}^{2}\end{array}$ & Adhesion energy, $\mathrm{G} / \mathrm{J} \cdot \mathrm{m}^{-2}$ \\
\hline $99.9 \% \mathrm{Fe}$ & 12.9 & 0.306 & $2.64 \times 10^{-9}$ & 2.90 \\
$\mathrm{Fe}-1.0 \% \mathrm{C}$ & 31.4 & 0.261 & $1.37 \times 10^{-9}$ & 31.6 \\
\hline
\end{tabular}


G が $99.9 \%$ 純鉄よりも大きくなったと考えられる.

次にヤング率に及ぼすボイドの影響について考察する。 ボ イドが増加するとスケールの密度は低下するが, $\mathrm{Fe}_{2} \mathrm{O}_{3}$ スケー ルで密度の小さいスケールほどヤング率が低減することが報 告されており ${ }^{15)}, \mathrm{Fe}-1.0 \% \mathrm{C}$ で見られたボイドが多い, つま り密度の小さい $\mathrm{Fe}_{3} \mathrm{O}_{4}$ スケールでも同様にヤング率が低減し たと考えられる。一方で，本研究において引張試験およびス クラッチ試験における密着エネルギーの導出に用いた式 $(3)$ (6)ではいずれもスケールのヤング率が重要な要素である. 同じ密着エネルギーを持つスケールであれば, ヤング率の小 さい方が，ひずみエネルギーが蓄積しにくく，より大きな変 形に耐えることができるため, 密着性は優れると考えられる. 今回の密着エネルギーの導出において, スケールのヤング率 は一律で $200 \mathrm{GPa}$ としているが, 前述のとおりスケール密度 の小さい $\mathrm{Fe}-1.0 \% \mathrm{C}$ ではヤング率が小さくなっていた可能性 があるため, 密着エネルギーは高く見積もられた可能性があ る. 前述の通り $\mathrm{Fe}-1.0 \% \mathrm{C}$ では $99.9 \%$ 純鉄に比べ残留応力が 低減しているが，スケールの残留応力は鋼とスケールの熱膨 張率差に起因する熱応力であり，式 (9)で示すように ${ }^{16)}$, 熱 応力とヤング率は比例関係にある.

$\sigma_{o}:$ 熱応力

$$
\sigma_{o}=E_{o}\left(\alpha_{o}-\alpha_{M}\right) \Delta T
$$

$$
E_{0}: \text { スケールのヤング率 }
$$

$\alpha_{o}:$ スケールの熱膨張係数

$\alpha_{M}:$ 鋼の熱膨張係数

$\Delta T:$ 温度差

すなわち $\mathrm{Fe}-1.0 \% \mathrm{C}$ で残留応力が低減していることからス ケールのヤング率が低下したことが示唆される。より正確な 密着エネルギーを導出するためには，スケールのヤング率を 把握することが課題となる.

\section{6. 結 言}

引張応力負荷時の鋼の変形を考慮したスケール状態は三段 階に分けられる. 99.9\%純鉄と $\mathrm{Fe}-1.0 \% \mathrm{C}$ において, 引張試 験によりスケールの密着性の定量評価を行った結果, スケー ルの密着エネルギーはそれぞれ $1.70 \mathrm{~J} / \mathrm{m}^{2}, 36.2 \mathrm{~J} / \mathrm{m}^{2}$ となり， スクラッチ試験での測定值 $2.90 \mathrm{~J} / \mathrm{m}^{2}, 31.6 \mathrm{~J} / \mathrm{m}^{2}$ と概ね一致し た。

\section{文献}

1) T. Asai and T. Towada: CAMP-ISIJ 11 (1998) 1079-1082.

2) T. Asai, T. Nakamura and T. Inoue: CAMP-ISIJ 6(1993) 1734.

3) H. Okada, T. Fukagawa, H. Ishihara, A. Okamoto, M. Agatsuma and Y. Matsuda: Tetsu-to-Hagané 80 (1994) 849-854.

4) T. Fukagawa, H. Okada and T. Fujikawa: Tetsu-to-Hagané 83 (1997) 305.

5) T. Wada, S. Oshimi, T. Nakamura, K. Esaka and T. Sachika: CAMP-ISIJ 1 (1988) 1875.

6) T. Nakamura, K. Esaka, S. Kato and H. Abe: CAMP-ISIJ 1 (1988) 1874.

7) T. Kizu, Y. Nagataki, T. Inazumi and Y. Hosoya: CAMP-ISIJ 13 (2000) 1088-1091.

8) H. Kushida, Y. Maeda and H. Ishikawa: Tetsu-to-Hagané 98 (2012) 593-600.

9) Y. Hidaka, T. Anraku and N. Otsuka: CAMP-ISIJ 13(2000) 1099

10) E. Iwamura: J. Surf. Finish. Soc. Jpn. 58(2007) 260-266.

11) H. E. Evans: International Materials Reviews 40 (1995) 1-40.

12) Somrerk Chandra-amnhorn et al: Mater. Sci. Technol. 23 (2007) 497.

13) M. Nakamura, K. Miura, T. Matsuoka and T. Hirayama: Journal of the Society of Materials Science, Japan 56(2007) 667-674.

14) K. Nishida and T. Narita: Introduction to High Temperture Oxidation of Metals, (Maruzen, Tokyo, 1988) pp. 185-194.

15) I. Saeki, T. Ohno, D. Seto, O. Sakai, Y. Sugiyama, T. Sato, A. Yamauchi, K. Kurokawab, M. Takeda and T. Onishic: Materials at High Temperatures 28(2011) 264-268.

16) Y. Saito, T. Atake and T. Maruyama: Kinzoku no koonsanka (Uchida Rokakuho, Tokyo, 1986) pp. 111-112. 